\title{
Characterization of Some Commercially Important Octopus (Mollusca: Cephalopoda) from Indonesian Waters using Mitochondrial DNA Cytochrome Oxidase Sub-Unit I (Mt-DNA COI)
}

\author{
Nenik Kholilah ${ }^{1 *}$, Norma Afiati ${ }^{2}$ and Subagiyo ${ }^{1}$ \\ ${ }^{1}$ Marine Science Department, Faculty of Fisheries and Marine Science, Diponegoro University \\ ${ }^{2}$ Aquatic Resources Department, Faculty of Fisheries and Marine Science, Diponegoro University \\ JI. Prof. H. Soedarto, S.H. Tembalang Semarang, 50275 Indonesia \\ Email: nenikkholil@gmail.com
}

\begin{abstract}
As per the FAO data, octopus identification is very limited in the species level at world fishery and also they are cryptic nature. On the other hand, Indonesia is one of the top ten highest octopus exporters. This study therefore aimed to determine the species of octopus based on phylogenetic analysis of mt-DNA COI. Octopuses were collected from nine different locations throughout Indonesia, i.e., Anambas, Bangka-Belitung, Cirebon, Karimunjawa, Tuban, Lombok, Buton, Wakatobi and Jayapura. Samples were mostly in the form of tentacles that were directly collected

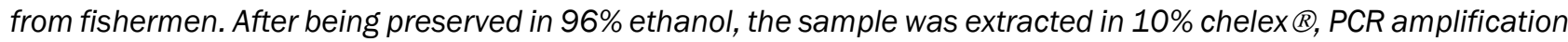
using Folmer's primer then was further analysed by sequencing in Sanger methods. Of the 24 samples sequenced, the results recognized four species Octopodidae belongs to the three genera, named Amphioctopus aegina, Hapalochlaena fasciata, Octopus laqueus and Octopus cyanea. Mean pair-wise distances of within-species were ranged from 0 to $5.5 \%$ and between-species was ranged from 12.9 to $15.8 \%$. This study distinctly confirmed the difference between genus Amphioctopus and Hapalochlaena (15.5\%), as also between O. laqueus and O. cyanea (12.9\%) which was previously not completely distinguished. Although performing species identification using DNA sequences for shallow-water benthic octopus species is perhaps considered premature, this study indicated the possible application of $\mathrm{COI}$ sequences for species identification, thereby providing a preliminary dataset for future DNA barcoding of octopus, in particular for Indonesia waters.
\end{abstract}

Keywords: Indonesia waters, Octopus, Mt-DNA, COI

\section{Introduction}

Octopus can be found in several of Indonesian waters such as around Kalimantan, Sulawesi, Maluku and Banda (Budiyanto and Sugiarto, 1997). At present, octopus caught to be used in export commodity was harvested from around 90 countries (Sauer et al., 2019) including Indonesia. Every year the global export demand for octopus continues to increase, but landings are decreasing and therefore the prices continue to increase (Nieuwenhove et al., 2019). This kind of shellfish is captured from nature in various ways, such as the use of trawls (Melis et al., 2018), traps (Sobrino et al., 2011), spear guns (Sauer et al., 2011; Benbow et al., 2014) or metal spears or sticks are also used by traditional fishermen in Hawaii, Tonga, Tokelau (Amstrong et al., 2011; TiraaPassfiled, 1999) and in Karimunjawa (this study).

Octopus has the ability to very quickly change color according to the substrate for camouflage; when they die the color immediately turns pale. Some whole-body samples for this study came in pieces as they were to be used as fishing bait. This resulted in morphological identification only down to the family level. Based on the FAO statistical data so far, only four species were categorized based on their morphological analysis out of more than 300 species that have been discovered in the world, namely Octopus vulgaris (Cuvier, 1979), O. maya (Voss and Solis-Ramirez, 1966), Eledone cirrhosa (Lamarck, 1798) and E. moschata (Lamarck, 1798).

According to the World Food Organization (FAO), in 2013 Indonesia is one of the top ten octopus exporters after Morocco, China, Spain and others (Suhana, 2020; Suriyani, 2020). In 2020, octopus exports were ranked third in Indonesia's fisheries commodity after shrimp and tuna (Paino, 2020). Whilst in 2014 the number decreased to 6.833 tons of octopus compared to the previous year, the export volume then increased from 2016 to 2019 by around 19.000 tons per year with an average value of USD 98 million per year (Suriyani, 2020). The continued capture of large numbers of octopuses without the correct identification of the species allows for the accidental overexploitation of certain species. This 
overexploitation can lead to the extinction of this species (Nieuwenhove et al., 2019), although this may also occur due to several factors such as parasites and pathogens (Rowley et al., 2014), pollution, exploitation and climate change (Gimenez, 2019).

Research using phylogenetic analysis of octopus was conducted by Amor et al. (2017) for the confirmation of the species 0 . vulgaris. The results of the study indicate that in fact not all samples of 0 . vulgaris were confirmed correctly according to molecular results, because this is a cryptic organism (Amor et al., 2019). This species has a very high fishery market value and profile thus, it will benefit market participants if all types of octopus are claimed to be 0 . vulgaris. In view of this, the role of molecular studies with phylogenetic analysis is very important as a basis for conducting appropriate policies. Therefore, FAO always tries to identify fishery products landed to the species level (Rodhouse, 2005). Correct identification can also be useful for capture and export management in order to maintain the sustainability of the population of the octopus. With the current development of molecular biology, this study was attempted to precisely identify the species of octopuses obtained from several regions in Indonesia by using mitochondrial DNA Cytochrome Oxidase Sub-Unit I (Mt-DNA COI) as a genetic marker.

Species identification using morphological approaches requires high degree of experienced specialist and becomes impractical for those interested to simply study the diversity of organism (Bilgin et al., 2015, Hebert et al., 2003; Radulovici et al., 2010). Hebert et al. (2003) proposed the use of
Mt-DNA COI as part of the DNA barcoding framework as a standard to identify species, define species boundaries and aid in species delimitation. More than four hundred DNA barcoding papers have been published since 2003 (Taylor and Harris, 2012). Previous research to determine species using mt-DNA COI have been carried out such as in cephalopods (Carlini and Graves, 1999; Hwang et al., 2016), decapods (da Silva et al., 2011; Bilgin et al., 2015; Kholilah et al., 2018), copepods (Bucklin et al., 1999; Baek et al., 2016; Francis et al., 2018), fish (Madduppa et al., 2016; Zeng et al., 2017), giant clam (Findra et al., 2017) and for unknown species; in particular trace amounts of tissues can be used as samples (Galal-Khallaf et al., 2016). In this study, phylogenetic analysis of mt-DNA $\mathrm{COI}$ is used to determine the species of octopus.

\section{Materials and Methods}

Octopus samples were collected from various landing centers of Indonesia during the period of 2015 to 2020 (Figure 1.). The samples from Cirebon and Tuban were caught in May and August 2015 and analyzed subsequently. The samples from Anambas were captured in October 2019, while samples from other locations were collected in 2020, i.e., Karimunjawa in January, Buton and Wakatobi in March, Bangka-Belitung in April then Jayapura in September 2020 (Figure 1.).

Octopuses were received directly from fishermen. Subsequently, samples were taken from the tentacles using sterilized devices, put into $96 \%$ ethanol and labeled. Sample documentation was only available for octopus from Wakatobi, Anambas,

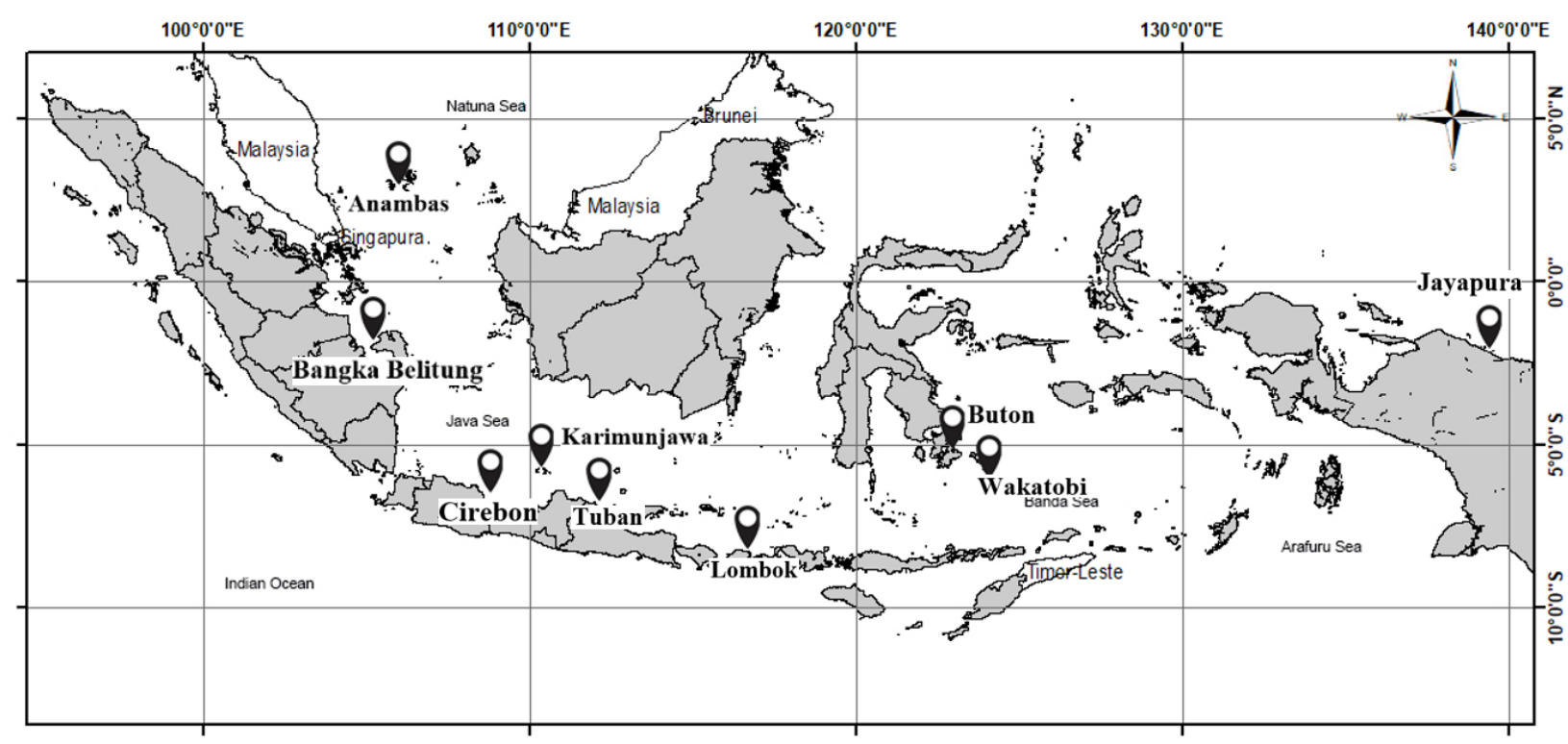

Figure 1. Sampling location of octopus in Indonesia waters 
Jayapura and Karimunjawa (Figure 2.). Meanwhile, octopus from Bangka-Belitung, Tuban and Cirebon have no documentation due to the existing limitations in the field because samples were received in a state that is no longer intact. Upon arrival at the laboratory, all preservatives were replaced with new $96 \%$ ethanol and were kept in the $4^{\circ} \mathrm{C}$ freezer until further analyses.

This study used a molecular genetic approach to the mitochondrial DNA of Cytochrome Oxidase subunit I (mt-DNA COI) locus of the octopus. DNA extraction was conducted using 10\% Chelex method (Walsh et al., 1991). Mt-DNA fragment was amplified using thermocycler machine and Polymerase Chain Reaction (PCR) methods with forward primer LC01490: 5'- GGT CAA CAA ATC ATA AAG ATA TTG G 3' and reverse primer HCO2198: 3'- TAA ACT TCA GGG TGA CCA AAA AAT CA -5' (Folmer et al., 1994). The composition of the $25 \mu \mathrm{l} \mathrm{PCR}$ cocktail was $1 \mu \mathrm{l}$ DNA template, $0.5 \mu$ l of each primer at $10 \mathrm{mM}, 12.5 \mu \mathrm{l}$ of Bioline master mix and $10.5 \mu \mathrm{lddH} 20$. The amplification method including initial denaturation $94^{\circ} \mathrm{C}$ for $5 \mathrm{~min}, 35$ cycles of denaturation $94^{\circ} \mathrm{C}$ for 1 min, annealing $56^{\circ} \mathrm{C}$ for $1 \mathrm{~min}$, extension $72{ }^{\circ} \mathrm{C}$ for $1.5 \mathrm{~min}$ with final extension $72^{\circ} \mathrm{C}$ for $1.5 \mathrm{~min}$. PCR products were visualized using $1 \%$ of agarose gel stained with Biotium ${ }^{\circledR}$ gel red stain. The successfully PCR products were sent to a DNA Sequencing facility to get sequenced using Sanger methods.

The sequence was then aligned using MEGA $X$ (Kumar et al., 2018). The species identity was determined by comparing sequences to GenBank

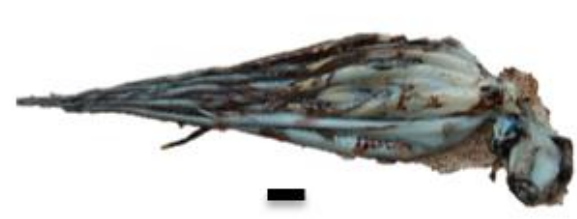

a. 158_Wakatobi

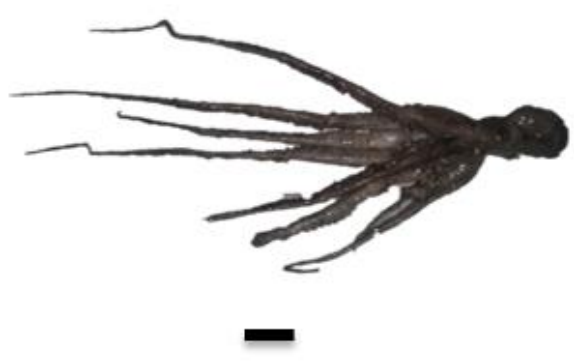

c. 244_Jayapura database (www.ncbi.nlm.nih.gov) enforcing a homology threshold of >99 \% (Malik et al., 2020; Pertiwi et al., 2020). Identification using phylogenetic tree was also reconstructed using Bayesian method with BEAST2 package program (Drummond et al., 2007; Bilderbeek and Etienne, 2018). The best fit model of molecular evolution for each portioning data was determined using Bayesian Information Criterion (BIC) in jModeltest program (Posada, 2008) and HKY (Hasegawa Kishino \& Yano) was selected as the best model. The Markov Chain Monte Carlo (MCMC) analysis with a random starting tree was run for 10 million generations.

\section{Results and Discussion}

Octopus can be found from shallow water (Heukelem, 1976) to deep water of $2.000 \mathrm{~m}$ (Robinson et al., 2014). This causes the shallow waters octopus in certain seasons to be less difficult for fishermen to find along the coastline. Usually, fishermen do snorkel on sand or coral substrate to catch shallow waters octopus using a spear gun. The total sample of octopus obtained from 9 locations in this study were $24 \mathrm{indv}$, they were all from coastal waters. Some photographic documentation can be seen in Figure 2.

Following Kaneko et al. (2011) whose working on octopus using $\mathrm{COI}$ marker and obtained $657 \mathrm{bp}$, present study generated the $685 \mathrm{bp}$ mt-DNA COI data for the 24 individuals belonging to the 4 species of three genera which all belong to the family Octopodidae.

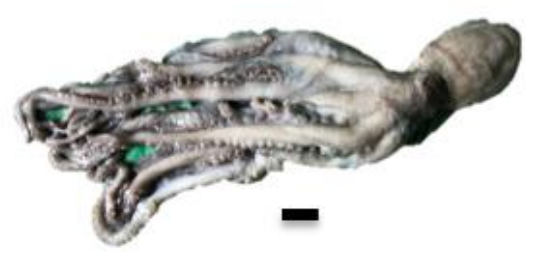

b. 144_Anambas

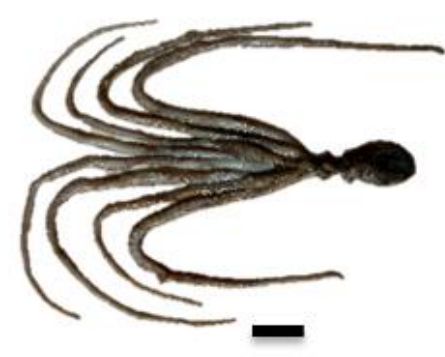

d. 118_Karimunjawa

Figure 2. Some octopus specimens from Wakatobi, Anambas, Jayapura (O. cyanea) and Karimunjawa (O. laqueus), Indonesia. Scale: $5 \mathrm{~cm}$ 
Table 1. BLAST identification for octopus from Cirebon, Tuban, Karimunjawa, Anambas, Wakatobi, Buton, Bangka-Belitung, Lombok and Jayapura - Indonesia

\begin{tabular}{|c|c|c|c|c|c|c|}
\hline No & Sample ID & BLAST result & $\begin{array}{c}\text { Accession } \\
\text { number }\end{array}$ & $\begin{array}{l}\text { Sequence } \\
\text { length (bp) }\end{array}$ & $\begin{array}{l}\text { Ident } \\
(\%)\end{array}$ & $\begin{array}{c}\text { Query } \\
\text { Cover } \\
(\%)\end{array}$ \\
\hline 1. & CG1_Cirebon & A. aegina & LC553345 & 685 & 100 & 100 \\
\hline 2. & CG2_Cirebon & A. aegina & LC553346 & 685 & 100 & 100 \\
\hline 3. & CG3_Cirebon & A. aegina & LC553347 & 685 & 100 & 100 \\
\hline 4. & TG1_Tuban & H. fasciata & LC553363 & 685 & 100 & 90 \\
\hline 5. & TG2_Tuban & H. fasciata & LC553364 & 685 & 100 & 90 \\
\hline 6. & TG3_Tuban & H. fasciata & LC553365 & 685 & 100 & 90 \\
\hline 7. & 22_Karimunjawa & O. laqueus & LC552307 & 685 & 100 & 95 \\
\hline 8. & 114_Karimunjawa & O. laqueus & LC552338 & 685 & 100 & 96 \\
\hline 9. & 117_Karimunjawa & O. laqueus & LC552341 & 685 & 100 & 96 \\
\hline 10. & 138_Anambas & O. cyanea & MW556215 & 685 & 99.71 & 99 \\
\hline 11. & 139_Anambas & O. cyanea & MW556216 & 685 & 99.71 & 99 \\
\hline 12. & 144_Anambas & O. cyanea & MW556217 & 685 & 100 & 99 \\
\hline 13. & 149_Lombok & O. cyanea & MW556220 & 685 & 99.85 & 99 \\
\hline 14. & 150_Lombok & O. cyanea & MW556221 & 685 & 99.85 & 99 \\
\hline 15. & 151_Wakatobi & O. cyanea & MW556222 & 685 & 100 & 99 \\
\hline 16. & 158_Wakatobi & O. cyanea & MW556224 & 685 & 99.71 & 99 \\
\hline 17. & 171_Wakatobi & O. cyanea & MW556228 & 685 & 99.71 & 99 \\
\hline 18. & 206_Buton & O. cyanea & MW556232 & 685 & 99.85 & 99 \\
\hline 19. & 207_Buton & O. cyanea & MW556233 & 685 & 99.85 & 99 \\
\hline 20. & 208_Buton & O. cyanea & MW556234 & 685 & 99.85 & 99 \\
\hline 21. & 211_Bangka-Belitung & O. laqueus & MW559642 & 685 & 92.07 & 95 \\
\hline 22. & 212_Bangka-Belitung & O. laqueus & MW559643 & 685 & 92.07 & 95 \\
\hline 23. & 243_Jayapura & O. cyanea & MW556237 & 685 & 99.85 & 99 \\
\hline 24. & 244_Jayapura & O. cyanea & MW556237 & 685 & 99.85 & 99 \\
\hline
\end{tabular}

Three specimens from each species of $A$. aegina (Gray, 1849) and H. fasciata (Hoyle, 1886), 5 specimens from 0 . laqueus (Kaneko and Kubodera, 2005) and 13 specimens from O. cyanea (Gray, 1849) were used in the study subsequently (Table 1.). BLAST results performed a percent identification value ranging from $92.07-100 \%$ and a percent value for query cover ranging from $95-100 \%$ (Table 1.) confirmed the presence of four species. This finding is indeed supported by the phylogenetic tree that showed 4 clades (Figure 3.), for which every clade represents groups of the same species.

Kaneko et al. (2011) stated that in their study Amphioctopus was not completely distinguished because it sometimes formed a clade together with Hapalochlaena, which showed morphological affinities with Amphioctopus. Here, Figure 3 (80\% posterior probability) illustrated that Amphioctopus and Hapalochlaena were completely different species with $15.5 \%$ interspecific divergence (Table 2.). This was also the case for 0 . laqueus and O. cyanea which according to Kaneko et al. (2011) were recognized as distinct groups, although the phylogenetic support for these groups was weak. In this study interspecific divergence between the two species was significant, i.e., $12.9 \%$ (Table 2.) supported by $77 \%$ posterior probability (Figure 3.).

Leray et al. (2013) suggested that the minimum percentage of identity to state species similarity was $98 \%$. Almost all samples in this study showed an identity percentage higher than $98 \%$. However, samples from Bangka-Belitung exhibit a low value $(92.07 \%)$. This was perhaps because the comparative data available in GenBank was only for a handful of octopus species, regardless the more or less 300 species that had been identified morphologically (Jereb et al., 2016). Furthermore, the analysis of intraspecific divergence showed that 0 . laqueus, which was comprised of samples from 
Bangka-Belitung and Karimunjawa, had the highest value for the within-species genetic distance, i.e., with an average of $5.5 \%$ (Table 2.). The specimen which was used in this study had been registered in the GenBank (Table 2.). Moreover, many cephalopod species that existed in Indonesia waters were yet geographically nor molecularly recorded in the international authorities, such as OBIS, WORMS, EOL, GBIF or UBIO, including these four species studied.
The geographical distribution of octopus taken from the nine areas of Indonesia waters was shown in Figure 4. A. aegina found in Cirebon, West Java, as commonly called sand bird or marbled octopus. They have a geographic distribution in Asia waters at a depth of $30 \mathrm{~m}-120 \mathrm{~m}$, ranged from the East Indian Ocean, south of Malaysia to Indonesia, west to Chennai, India and the Philippines (Norman et al., 2013). H. fasciata or blue-lined octopus in this study

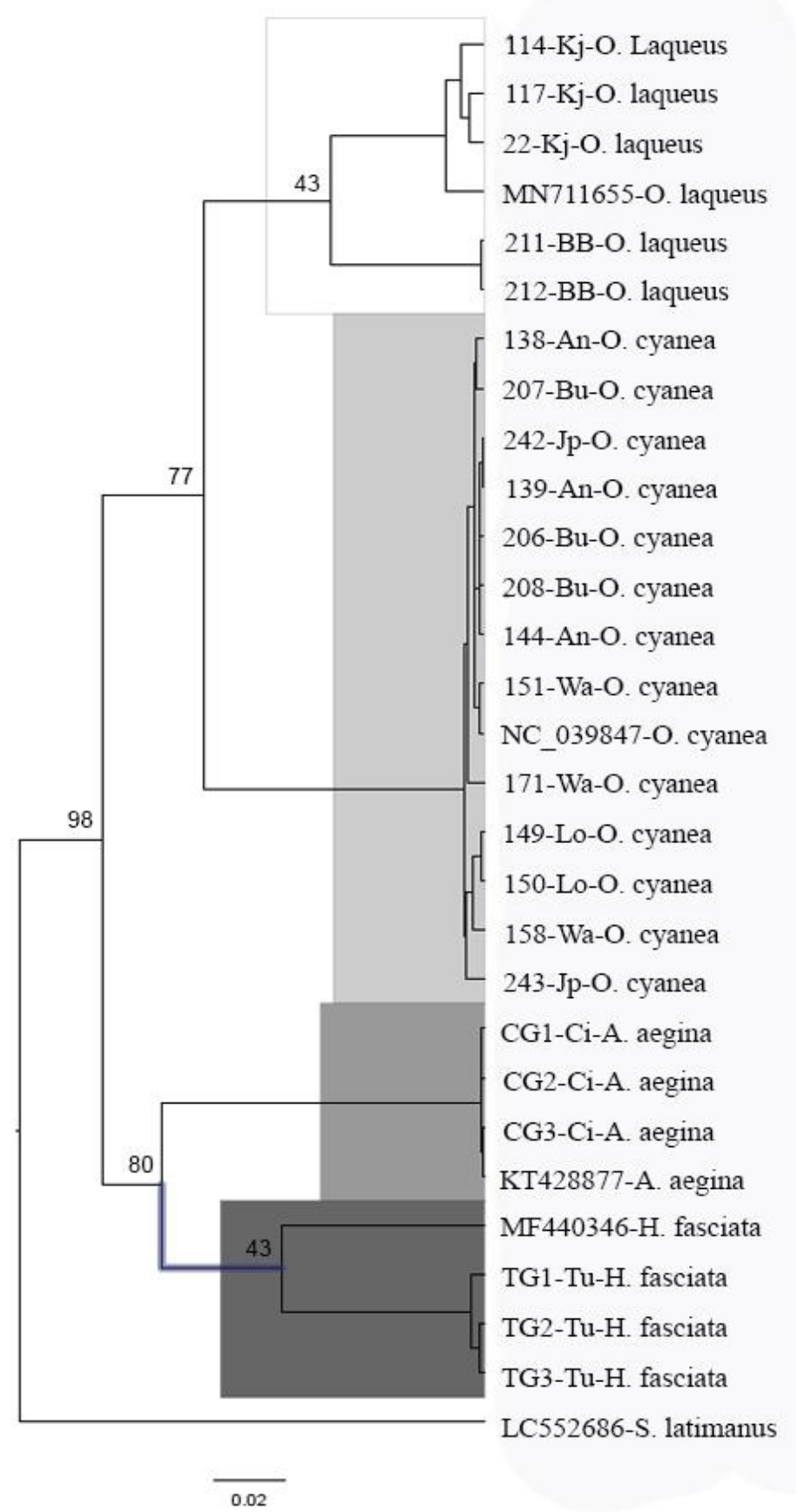

Figure 3. Phylogenetic tree of octopus samples from nine locations (Table 1.), analyzed using Bayesian methods. The node number represents posterior probabilities value. O. laqueus (MN711655), O. cyanea (NC_039847), A. aegina (KT428877) and H. fasciata (MF440346) were used as in group and Sepia latimanus (LC552686) was used as an outgroup. Each gradation color (darker to lighter) represent the species clade 
ILMU KELAUTAN: Indonesian Journal of Marine Sciences March 2021 Vol 26(1):17-26

Table 2. Mean pair-wise distances of within-species and between-species of the four studied octopus

\begin{tabular}{|c|c|c|c|c|}
\hline \multirow{2}{*}{ Species } & \multirow{2}{*}{$\begin{array}{c}\text { Within species mean } \\
\text { distance }\end{array}$} & \multicolumn{3}{|c|}{ Between species mean distance } \\
\hline & & A. aegina & H. fasciata & O. laqueus \\
\hline A. aegina & 0,000 & & & \\
\hline H. fasciata & 0,005 & 0,155 & & \\
\hline O. laqueus & 0,055 & 0,158 & 0,171 & \\
\hline O. cyanea & 0,002 & 0,147 & 0,157 & 0,129 \\
\hline
\end{tabular}

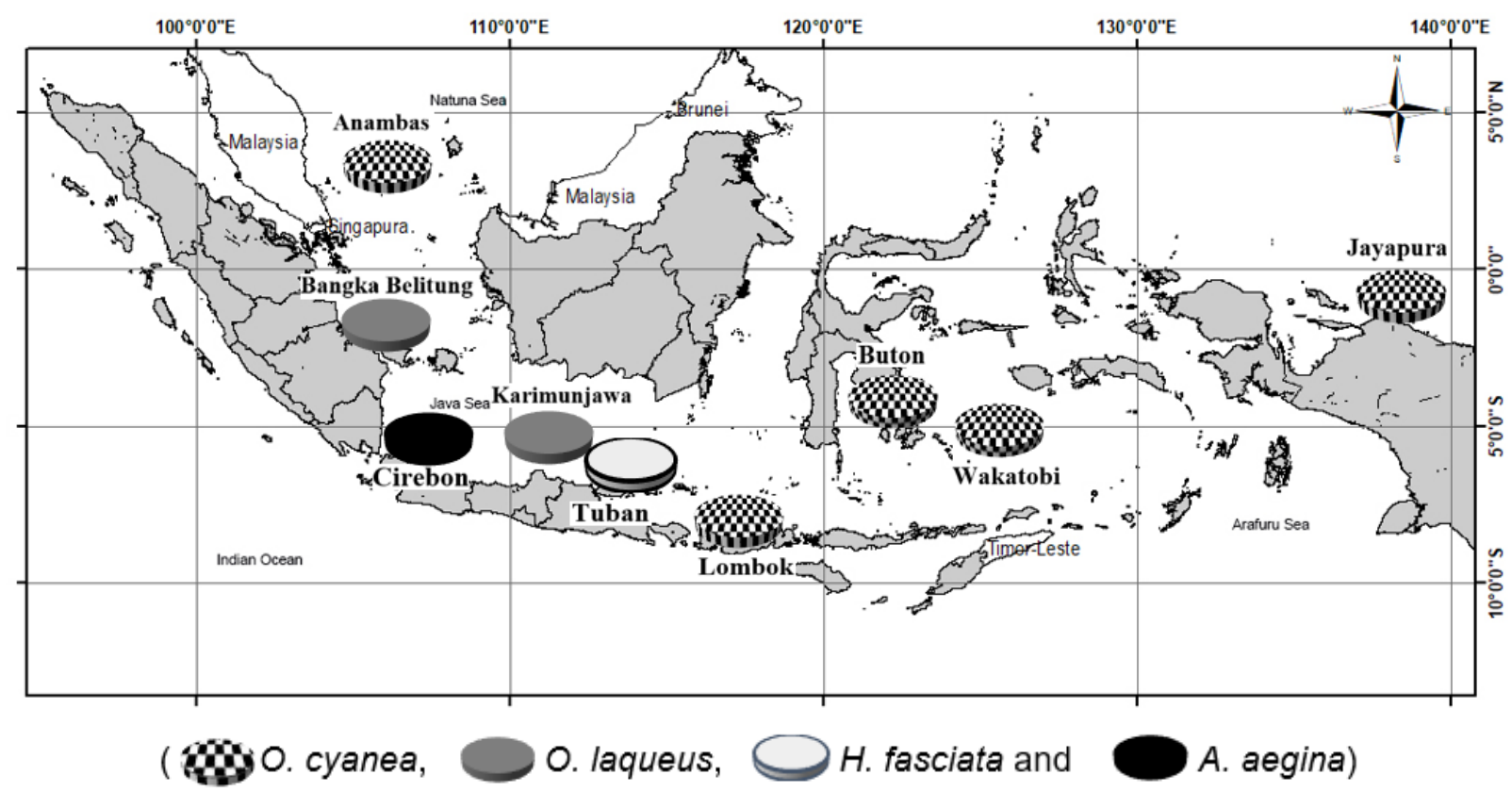

Figure 4. Geographical distribution of four octopus species studied in Indonesia waters

was found only in Tuban, East Java with the mean pair-wise distance within-species of 0,5\% (Table 2.). According to Jereb et al. (2016) this species occurs in subtropical waters of eastern Australia from southern Queensland to southern New South Wales. They are distributed at a depth of $0-20 \mathrm{~m}$ on shallow and intertidal coral substrates. O. laqueus was first discovered in the Ryukyu Islands, Japan (Kaneko and Kubodera, 2005). This nocturnal O. laqueus was a tropical species commonly found living on sand and coral reef substrates and was scattered in the IndoPacific (Ikeda, 2009; Kaneko and Kudodera, 2005). In this study, it was collected in the waters of BangkaBelitung and Karimunjawa. In the latter location, it was found seasonally, i.e. only from January February throughout the 2018 - 2020 period.

O. cyanea was the most common species found in Anambas, Buton, Wakatobi and Lombok with the mean pair-wise distance within-species is $0,2 \%$ which represented the same species. 0 . cyanea was commonly called big blue octopus or day octopus. and was distributed along the Indo-Pacific at shallow depth. In the benthic environment, it was active at night and remained in its nest during the day (Scheel and Bisson, 2012). This is one of the best-adapted species to climate change amongst the 40 marine organisms mostly exploited species for commercial purposes (Sauer et al., 2011), O. cyanea can issue up to 150,000 - 700,000 eggs (Van Heukelem, 1976). Planktonic larvae of 0 . cyanea will be carried in the water column for 1-2 months before settling (Raberinary and Benbow, 2012). This causes its distribution to be very wide, reaching hundreds of kilometers with the help of currents (Casu et al., 2002; Murphy et al., 2002). Thus, it may explain its wide geographic distribution throughout the Indonesian waters (Figure 4.).

\section{Conclusion}

This study recognized four octopus' species, i.e., A. aegina, $H$. fasciata, O. laqueus and O. cyanea. Among the nine widespread sampling locations in Indonesia waters, the species with the widest geographical distribution is 0 . cyanea, they can be 
found in Anambas, Lombok, Buton, Wakatobi and Jayapura-Papua. Whereas, the venomous species $H$. fasciata was found only in Tuban, East Java. Regarding the methods, $10 \%$ chelex extraction followed by the use of universal Folmer"s primer LCO1490/HCO2198 proved to be the most suitable for octopus in this study.

\section{Acknowledgment}

Part of this paper covers the work conducted for the author's Master degree at the Universitas Diponegoro, Semarang - Indonesia. The authors would like to express gratitude to Mr. Fadli Jaka K., Mr. Wadu Marsidik (Buton Marine and Fisheries Office), Mr. Samsu Adimahu (Wakatobi), Mr. Fajar Bayu Aji, Mr. Umam Komarullah (CEO of Koralko Bangka-Belitung), Mr. Cahya Himawan (staff of WCS Lombok) and Mr. John Dominggus Kalor (Lecturer of the Department of Marine Science, Cendrawasih University, Jayapura) who kindly supplied octopus specimens used in this study. This paper is part of The Universitas Diponegoro's Seeded Fundamental Research Grant funded by the Directorate General of Higher Education, Ministry of Education and Culture of the Republic of Indonesia under contract Number. 101-12/UN7.P4.3/PP/2019, awarded to Norma Afiati, Subagiyo and Retno Hartati.

\section{References}

Amor, M.D., Norman, M.D., Roura, A., Leite, T.S., Gleadall, I.G., Reid, A., Raya, C.P., Lu, C.C., Silvey, C.J., Vidal, E.A.G., Hochberg, F.G., Zheng, X. \& Strugnell, J.M. 2017. Morphological Assessment of the Octopus vulgaris Species Complex Evaluated in Light of Molecular-based Phylogenetic Inferences. Zoolog. Scripta. 46(3): 275-288. doi: 10.1111/zsc.12207.

Amor, M.D., Doyle, S.R., Norman, M.D., Roura, A., Hall, N.E., Robinson, A.J., Leite, T.S. \& Strugnell, J.M. 2019. Genome-wide Sequencing Uncovers Cryptic Diversity and Mito-nuclear Discordance in the Octopus vulgaris Species Complex. BioRxiv. 1-36. doi: 10.1101/573493.

Amstrong K., Herdrich, D \& Levine, A. 2011. Historic Fishing Methods in American Samoa. NOAA Tech. Mem. NMFS-PIFSC-24. pp. 70.

Baek, S.Y., Jang, K.H., Choi, E.H., Ryu, S.H., Kim, S.K., Lee, J.H., Lim, Y.J., Lee, J., Jun, J., Kwak, M. \& Lee, Y.S. 2016. DNA Barcoding of Metazoan Zooplankton Copepods from South Korea. PloS ONE. 11(7): e0157307. doi: 10.1371/ journal.pone.0157307.
Benbow, S., Humber, F., Oliver, T.A., Oleson, K.L.L., Raberinary, D., Nadon, M., Ratsimbazafy, H. \& Harris, A., 2014. Lessons Learnt from Experimental Temporary Octopus Fishing Closures in South-West Madagascar: Benefits of Concurrent Closures. African J. Mar. Sci., 36(1): 37-41. doi: 10.2989/181 4232X.2014. 893256.

Bilderbeek, R. \& Etienne, R.S. 2018. Babette: BEAUTi 2, BEAST and Tracer for R. BioRxiv. 1-17. doi: 10.1101/271866.

Bilgin, R., Utkan, M.A., Kalkan, E., Karhan, S.U. \& Bekbölet, M., 2015. DNA Barcoding of Twelve Shrimp Species (Crustacea: Decapoda) from Turkish Seas Reveals Cryptic Diversity. Mediterr. Mar. Sci., 16: 36-45. doi: 10.12681/mms.548.

Bucklin, A., Guarnieri, M., Hill, R.S., Bentley, A.M. \& Kaartvedt, S. 1999. Taxonomic and Systematic Assessment of Planktonic Copepods using Mitochondrial $\mathrm{COI}$ Sequence Variation and Competitive, Species-specific PCR. Hydrobiologia. 401: 239-240. doi: 10.1023/A:1003790 411424.

Budiyanto A. \& Sugiarto, H. 1997. Catatan Mengenai si Tangan Delapan (Gurita/Octopus spp.). Oseana. 22(3): 25-33.

Carlini, D.B. \& Graves, J.E. 1999. Phylogenetic Analysis of Cytochrome C Oxidase 1 Sequences to Determine Higher-Level Relationships within the Coleoid Cephalopods. Bul. Mar. Sci., 64(1): 57-76.

Casu, M., Maltagliati, F., Meloni, M., Casu, D., Cossu, P., Binelli, G., Curini-Galletti, M. \& Castelli, A. 2002. Genetic Structure of Octopus vulgaris (Mollusca, Cephalopoda) from the Mediterranean Sea as Revealed by a Microsatellite Locus. Ital. J. Zool. 69: 295-300. doi: 10.1080/112500002093 56472.

da Silva, J.M., Creer, S., Dos Santos, A., Costa, A.C., Cunha, M.R., Costa, F.O. and Carvalho, G.R.2011. Systematic and Evolutionary Insights Derived from mtDNA COI Barcode Diversity in the Decapoda (Crustacea: Malacostraca). PIoS ONE. 6(5): E19449. doi: 10.1371/journal.pone.0019 449.

Drummond, A.J., Ho, S.Y.W., Rawlence, N. \& Rambaut, A. 2007. A Rough Guide to BEAST 1.4. The University of Edinburgh. Edinburgh, United Kingdom. 42 page.

Findra, M., Setyobudiandi, I., Butet, N. and Solihin, D. 2017. Genetic Profile Assessment of Giant Clam 
Genus Tridacna as a Basis for Resource Management at Wakatobi National Park Waters, IImu Kelautan: Indo. J. Mar. Sci., 22(2): 67-74. doi: 10.14710/ik.ijms. 22.2.67-74.

Folmer, O., Black, M., Hoeh, W., Lutz, R. \& Vrijenhoek, R. 1994. DNA Primers for Amplification of Mitochondrial Cytochrome C Oxidase Subunit I from Diverse Metazoan Invertebrates. Mol. Mar. Biol. Biotechnol., 3:294-299.

Francis, S.V., Nishida, S. \& Nandan, S.B. 2018. Validation of Male Pontella spinipes Giesbrecht, 1889 (Copepoda: Calanoida: Pontellidae) Based on Morphological and Mitochondrial COI Gene Sequence Analysis. Zool. Stud., 57(16): 1-11. doi: 10.6620/ZS.2018.57-16

Galal-Khallaf, A., Ardura, A., Borrell, Y.J. \& GarciaVazquez, E. 2016. Towards More Sustainable Surimi? PCR-Cloning Approach for DNA Barcoding Reveals the Use of Species of Low Trophic Level and Aquaculture in Asian Surimi. Food Control. 61: 62-69. doi: 10.1016/j.food cont.2015. 09.027.

Gibbs A.G. 1997. Biochemistry at Depth. In: Randall D.J.\& A.P. Farrell (eds) Deep-sea ®shes. Academic, San Diego, pp 239 \pm 271 .

Gimenez, L. 2019. Incorporating the Geometry of Dispersal and Migration to Understand Spatial Patterns of Species Distributions. Ecography. 42(4): 643-657. doi: 10.111 1/ecog.03493.

Hebert, P.D.N., Ratnasingham, S. \& Waard, J.R.D. 2003. Barcoding Animal Life: Cytochrome C Oxidase Subunit 1 Divergences Among Closely Related Species. Biol. Sci., 270:96-99. doi: 10.1098/rsbl.2003.0025.

Hwang, H.J., Kang, S.W., Park, S.Y., Chung, J.M., Song, D.K., Park, H., Park, H.S., Han, Y.S., Lee, J.S. \& Lee, Y.S., 2016. Classification and Phylogenetic Studies of Cephalopods from Four Countries of South-East Asia. Korean J. Malacol., 32: 55-62. doi: 10.9710/kjm.20 16.32.1.55.

Ikeda Y., 2009. A Perspective on the Study of Cognition and Sociality of Cephalopod Mollusks, a Group of Intelligent Marine Invertebrates. Jpn. Psychol. Res., 51(3):146-153. doi: 10.1111/j. 1468-5884.2009.004 01.x.

Jereb, P., Roper, C.F.E., Norman, M.D. \& Finn, K.J. 2016. Cephalopods of the World. An Annotated and Illustrated Catalogue of Species Known to Date. Octopods and Vampire Squids. FAO
Species Catalogue for Fishery Purposes. Vol.3. Roma, FAO. 370 page.

Kaneko N. \& Kubodera, T. 2005. A New Species of Shallow Water Octopus, Octopus laqueus, (Cephalopoda: Octopodidae) from Okinawa, Japan. Bull. Nat. Sci. Mus. Ser. A. 31: 7-20.

Kaneko, N., Kubodera, T. \& Iguchis. A. 2011. Taxonomic Study of Shallow-Water Octopuses (Cephalopoda: Octopodidae) in Japan and Adjacent Waters using Mitochondrial Genes with Perspectives on Octopus DNA Barcoding. Malacologia. 54(1-2): 97-108. doi: 10.4002/040.054. 0102

Kholilah, N., Al Malik, M.D., Kurniasih, E.M., Sembiring, A., Ambariyanto \& Mayer, C. 2018. Conditions of Decapods Infraorders in Dead Coral Pocillopora sp. at Pemuteran, Bali: Study Case 2011 and 2016. IOP Conf. Ser.: Earth Environ. Sci., 116p. doi: 10.1088/1755-1315/ 116/1/012070.

Kumar, S., Stecher, G., Li, M., Knyaz, C. \& Tamura, K. 2018. Mega X: Molecular Evolutionary Genetics Analysis Across Computing Platforms. Molecul. Biol. Evol., 35(6): 1547-1549. doi: 10.1093/mol $\mathrm{bev} / \mathrm{msy096.}$

Leray, M., Yang, J.Y., Mayer, C.P., Mills, S.C., Agudelo, N., Ranwes, V., Boehm, J.T. \& Machida, R.J. 2013. A New Versatile Primer Set Targeting a Short Fragment of the Mitochondrial COI Region for Metabarcoding Metazoan Diversity: Application for Characterizing Coral Reef Fish Gut Contents. Front. Zool., 10(1): 34. doi: 10.11 86/1742-9994-10-34.

Madduppa, H., Ayuningtyas, R., Subhan, B., Arafat, D. \& Prehadi. 2016. Exploited but Unevaluated: DNA Barcoding Reveals Skates and Stingrays (Chordata, Chondrichthyes) Species Landed in the Indonesian Fish Market, IImu Kelautan: Indo. J. Mar. Sci, 21(2): 77-84. doi : 10.14710/ik. ijms.21.2.77-84.

Malik, M.D.A., Pertiwi, N.P.D., Sembiring, A., Yusmalinda, N.L.A., Ningsih, E.Y. \& Astarini, I.A. 2020. Short communication: Genetic structure of Longtail Tuna Thunnus tonggol (Bleeker, 1851) in Java Sea, Indonesia. Biodiv., 21(8): 3637-3643. doi: 10.13057/biodiv/d210 828.

Melis, R., Vacca, L., Cuccu, D., Mereu, M., Cau, A., Follesa, M.C. and Cannas, R., 2018. Genetic Population Structure and Phylogeny of the Common Octopus Octopus vulgaris Cuvier, 1797 in the Western Mediterranean Sea 
Through Nuclear and Mitochondrial Markers. Hydrobiologia. 807: 277-296. doi: 10.1007/ s10750-017-3399-5.

Murphy, J.M., Baguerias, E., Key, L.N. \& Boyle, P.R. 2002. Microsatellites DNA Markers Discriminate Between Two Octopus vulgaris (Cephalopoda: Octopoda) Fisheries Along the Northwest African Coast. Bul. Mar. Sci., 71: 545-553.

Nieuwenhove, A.H.M.V., Ratsimbazafy, H.A. \& Kochzius. M. 2019. Cryptic Diversity and Limited Connectivity in Octopuses: Recommendations for Fisheries Management. PLOS ONE 14: 1-20. doi: 10.1371/journal. pone.0214748.

Norman, M.D., Finn, J.K. \& Hochberg, F.G. 2013. Family Octopodidae. In: Jereb, P, Roper, CFE, Norman MD, Finn JK, eds. Cephalopods of the World. An Annotated and Illustrated Catalogue of Cephalopod Species Know to Date: Octopods and Vampire Squids. FAO species catalogue for fishery purposes. Rome: FAO. p 68-69.

Paino, C. 2020. Hari Gurita Internasional, Saatnya Nasib Nelayan Gurita di Indonesia Diperhatikan.https://www.mongabay.co.id/202 0/10/14/hari-gurita-internasional-saatnyanasib-nelayan-gurita. Accessed 5 January 2021. [Indonesian]

Pertiwi, N.P.D., Suhendro, M.D., Yusmalinda, N.L.A., Putra, I.N.G., Putri, I.G.R.M., Artiningsih, E.Y., Malik, M.D.A., Cahyani, N.K.D. \& Sembiring, A. 2020. Forensic Genetic Case Study: Species Identification and Traceability of Sea Turtle Caught in Illegal Trade in Bali, Indonesia. Biodiversitas. 21(9): 4276-4283. doi: 10.130 57/biodiv/d210945.

Posada, D. 2008. jModelTest: Phylogenetic Model Averaging. Molecular Biology and Evolution. 25: 1253-1256. doi: 10.1093/ molbev/msn083.

Raberinary, D. \& Benbow, S. 2012. The Reproductive Cycle of Octopus cyanea in Southwest Madagascar and Implications for Fisheries Management. Fish. Res., 125: 190-197. doi: 10.1016/j.fishres.20 12.02.025.

Radulovici, A.E., Archambault, P. \& Dufresne, F. 2010. DNA Barcodes for Marine Biodiversity: Moving Fast Forward? Diversity. 2: 450-472. doi: 10.3390/d204 0450.

Robinson, B., Selbel, B. \& Drazen, J. 2014. Deep-Sea Octopus (Graneledone boreopacifica) Conduct the Longest-Known Egg-Brooding Period of Any
Animal. PLoS ONE. 9(7): 1-4. doi: 10.1371/jour nal.pone.0103437

Rowley, A.F., Cross, M.E., Culloty, S.C., Lynch, S.A., Mackenzie, C.L., Morgan, E., O'Riordan, R.M., Robins, P.E., Smith, A.L., Thrupp, T.J. \& Vogan, C.L. 2014. The Potential Impact of Climate Change on the Infectious Diseases of Commercially Important Shellfish Populations in the Irish Sea-a review. J. Mar. Sci., 71(4): $741-$ 759. doi: $10.1093 /$ icesjms/fst234.

Sauer, W.H., Gleadall, I.G., Downey-Breedt, N., Doubleday, Z., Gillespie, G., Haimovici, M., Ibáñez, C.M., Katugin, O.N., Leporati, S., Lipinski, M.R. and Markaida, U., 2019. World Octopus Fisheries. Rev. Fish. Sci. Aqua., Pp: 1-151. doi: 10.1080/23308249.2019.1680603.

Sauer, W.H.H., Potts, W., Raberinary, D., Anderson, J. \& Perrine, M.J.S. 2011. Assessment of Current Data for the Octopus Resource in Rodrigues, Western Indian Ocean. African J. Mar. Sci., 33: 181-187.

Scheel, D. \& Bisson, L. 2012. Movement Patterns of Giant Pacific Octopuses, Enteroctopus dofleini (Wulker, 1910). J. Exp. Mar. Biol. Ecol., 416417: 21-31. doi: 10.1016/j.jembe.2012.02. 004.

Sobrino, I., Juarez, A., Rey, J., Romero, Z. \& Baro, J. 2011. Description of the Clay Pot Fishery in the Gulf of Cadiz (SW Spain) for Octopus vulgaris: Selectivity and Exploitation Pattern. Fish. Res., 108: 283-290. doi: 10.1016/j.fishres.2010.12. 022.

Suhana. 2020. Bisnis Cumi-Sotong-Gurita Makin Menggurita. Available at: https://suhana.web. id/2020/02/03/bisnis-cumi-sotong-guritamakin-menggurita/. Accessed 5 Januari 2021. [Indonesian]

Suriyani, L.D. 2020. Meski Eksportir Terbesar, Perikanan Gurita Indonesia Belum Berkelanjutan. Available at: https://www.m ongabay.co.id/2020/11/25/meski-eksportirterbesar-perikanan-gurita-indonesia-belumberkelanjutan/. Accessed 5 Januari 2021.

Taylor, H. \& Harris, W. 2012. An Emergent Science on the Brink of Irrelevance: a Review of the Past 8 Years of DNA Barcoding. Mol. Ecol. Res., 3: 377388. doi: 10.1111/j.1755-0998.2012.03119.x.

Tiraa-Passfield A. 1999. Octopus Fishing by Women of Fakaofo Atoll, Tokelau Islands. SPC Tradit. Mar. Res. Manag. Know. Inf. Bull., 11: 11-12. 
ILMU KELAUTAN: Indonesian Journal of Marine Sciences March 2021 Vol 26(1):17-26

Van Heukelem, W.F. 1976. Growth, Bioenergetics, and Life-span of Octopus cyanea and Octopus maya. Thesis. University of Hawaii. Hawaii. 224p.

Voss, G.L. \& Solis, R.M.J. 1966. Octopus maya, a New Species from the Bay of Campeche, Mexico. Bull. Mar. Sci., 16: 615-625.

Walsh, P.S., Metzger, D.A. \& Higuchi, R. 1991. Chelex 100 as a Medium for Simple Extraction of DNA for PCR-based Typing from Forensic Material. BioTechniq, 10(4): 506-513.

Zeng, L., Wen, J., Fan, S., Chen, Z., Xu, Y., Sun, Y., Chen, D. \& Zhao, J. 2017. Species Identification of Fish Maw (Porcupinefish) Products Sold on the Market Using DNA Sequencing of $16 \mathrm{~S}$ rRNA and COI Genes. Food Control., 86: 159-162. doi: 10.1016/j.foodcont.20 17.11.031. 